Т. В. Мелкумова

\title{
ВИРАЖАЛЬНІ МОЖЛИВОСТІ РИТОРИЧНИХ ЗАПИТАНЬ У ПИСЕМНОМУ ІНФОРМАЦІЙНОМУ МОВЛЕННІ
}

Мелкумова Т. В. Виражальні можливості інформаційних запитань у писемному інформаційному мовленні.

У статті йдеться про один із засобів стилістичного синтаксису - риторичне питання. Функціонування риторичних питань розглядається на матеріалі власне інформацій-

$$
-101-
$$

(C) Т. В. Мелкумова, 2009. 
ного та коментарного різновидів інформаційного стилю. З'ясовується виражальнофункціональний потенціал риторичних питань в аналізованих текстах.

Ключові слова: риторичне запитання, виражальний засіб, стилістичний синтаксис, власне інформаційний текст, коментарне мовлення.

Мелкумова Т. В. Выразительные возможности риторических вопросов в письменной информационной речи.

В статье идет речь об одном из средств стилистического синтаксиса - риторическом вопросе. Функционирование риторических вопросов рассматривается на материале собственно информационной и коментарной разновидностей информационного стиля. Определяется выразительно-функциональный потенциал риторических вопросов в анализированных текстах.

Ключевые слова: риторический вопрос, выразительное средство, стилистический синтаксис, собственно информационный текст, комментарная речь.

Melkumova T. V. Expressive abilities of rhetorical questions in the writing information speech.

The article presents one of ways of stylistic syntacs - rhetorical question. The function of rhetorical questions is examined on the material of properly information and comment types of information style. The expressive-functional potential of rhetorical questions is also presented there.

Key words: rhetorical question, expressive way, stylistic syntacs, properly information text, comment speech.

Питально-риточні речення, або речення непрямої питальності (П. С. Дудик), або питальний риторичний зворот (В. С. Ващенко) - риторичні (за)питання - виражальний засіб стилістичного синтаксису, який полягає в наданні ствердженню або запереченню питальної форми. Риторичне питання - дуже давня риторична фігура, відома ще з часів античної риторики. 3. Т. Франко підкреслює поширеність риторичних запитань у новітній українській літературі, зазначає, що вони властиві епічному мовленню, але пасажами можуть вклинюватися i в ліричний план розповіді [6, 551]. П. С. Дудик зазначає: «Через те, що сутність питально-риторичних речень втілюється в специфічній питальній інтонації і що думка-судження в них виражається з особливою емоційністю, питально-риторичні речення широко представлені в багатьох творах художньої літератури, в публіцистиці, виконують функцію стилістично яскравого засобу мовлення» [3, 231].

П. С. Дудик, О. Д. Пономарів, авторські колективи посібників зі стилістики ілюструють теоретичні відомості про риторичні питання прикладами 3 художніх і публіцистичних стилів, ураховуючи високий виражально-функціональний потенціал їхніх текстів. Функціонування риторичних запитань в інформаційних текстах є малодослідженим, проте вельми цікавим в аспекті співставлення підстилів інформаційного мовлення за їхніми стилістичними можливостями. У статті висувається мета виявити риторичні питання у власне інформаційному та коментарному різновидах інформаційного стилю, з'ясувати виражальний потенціал риторичних питань в аналізованих текстах.

На відміну від функціонування риторичних питань у художньому та публіцистичному мовленні, у стилях нехудожніх, як зазначає В. С. Ващен- 
ко, риторичні фігури виступають із своєрідною помірною інтонацією, відносно зниженою та приглушеною. Проте й тут вони функціонують як досить витончені засоби увиразнення чи підкреслення окремих місць [2, 374]. До основних функцій риторичних питань дослідники відносять підвищення емоційного тону мовлення, посилення прагматичного ефекту висловлення (Н. І. Лихошерст [4, 159]), «зосередження уваги слухача на якихось семантико-стилістичних центрах мовного контексту, що досягається специфічним інтонуванням фрази» (В. С. Ващенко [2, 373]). Риторичне питання - фігура, що яскраво характеризується різноманітністю емоційноекспресивних відтінків (Ван Сіньї $[1,9])$.

Найперше, для чого слугують риторичні питання взагалі та в інформаційних текстах зокрема - емоційно стверджувати або заперечувати. Посилення виразності висловлень відбувається шляхом надання їм питальної форми: У більшості з них - теж ознака часу - висловлювали переконаність, щзо справа тут зовсім не в Будинку науково-технічної інформації як такому. Просто добротні приміщення на додачу до готелю «Саксагань» комусь в око запали. А заради них усі методи прийняті. Хіба тут до культури чи якоїсь духовності? [УМ. 01.08.2003] (заперечення, коментарне мовлення). Риторичні питання можуть містити «програму дій», відрізнятися конкретикою проблем: Та хіба не простіше зробити товари у звичайних магазинах доступнішими і працювати над поліпшенням рівня життя громадян, ніж обіцяти чергове сумнівне нововведення? [ВП. 12.03.2009] (ствердження, власне інформаційний різновид).

Риторичні питання вживаються для привернення уваги до певного явища: Манна небесна? [стосовно фінансування урядом «Програми аерокосмічного розвитку країни»] [ВП. 14.04.2009] (коментарне мовлення); Кому заважав «кадровик»? У Дніпропетровську вбили заступника начальника районного відділу мілічї, на території якого працювали три нарколабораторії [УМ. 24.01.2009] (власне інформаційний підстиль).

Риторичні питання використовуються як засіб відтворення діалогу 3 уявним співрозмовником, наприклад, у тексті коментарного різновиду: Дужсе саркастично, дуже згущені фарби? Можливо, й так. А хіба ми вже не переживали такого, коли в часи голодомору писали й показували тільки рожеве й оптимістичне? [СВ. 30.04.2009] - риторичне питання створює ілюзію спілкування, що начебто відбувається у присутності читача і за його участю, навіть якщо це не інформаційний жанровий різновид інтерв’ю. Значно рідше, ніж у коментарному мовленні, зустрічаємо зразки уявних діалогів і у власне інформаційних текстах: Марення психічно хворої людини? Hi, читачу, ие - російська фантастика - опус такого собі Григорія Савицького під назвою «Поле бою - Украӥна. Зламаний тризуб» [УМ. 28.02.2009] - у контексті монологічного інформаційного мовлення реакція на запитання здійснюється самим мовцем. 
Риторичне питання може використовуватися в авторській розповіді як засіб відтворення роздумів автора (у коментарному різновиді): $М u$ вже якось ставили запитання: а чому б для початку не створити, приміром, спільну корпорачію з розробки Тюменських нафтогазових родовищ? Чому ми постійно створюємо якісь кониерни й консориіуми з росіянами із використання винятково українських об'єктів народного господарства? [ДТ. 27.12.2003].

У власне інформаційному підстилі підвищено виразні риторичні запитання зустрічаються при введенні до тексту цитування, на зразок: Водночас для Лілії Степанівни зараз складно охарактеризувати нинішній стан партії. «Ми ухвалили суто технічні рішення: призначили засідання політради, гіпотетично домовились про з'їзд»-каже пані Григорович. «А щцо ще можнна сьогодні вирішувати? $\boldsymbol{C}$ коаліція чи немає? Спільність міжс БЮТ і Партією регіонів - с чи нема? Якщз Тимошенко каже, щзо ні, «та ніколи!», а Томенко каже «так», Азаров каже, що «нізащо», а Ганна Герман - «та звісно!» Це рішення?» [УМ. 15.04.2009]; «Ми два місяиі тому прийняли рішення... Я хочу запитати: які кайдани у вас на ногах, що ви 40 млн. гривень... не можете перерахувати Харківському авіаційному заводові? Я що, 24 години на добу повинна няньчити міністрів?» [УМ. 26.02.2009].

У текстах коментарного різновиду питальна інтонація в риторичній фігурі може виражати: а) подив - Чому в Кривому Розі позбуваються того, чим беззастережно пишалися протягом десятків років? [УМ. 01.08.2003]; б) іронію - Напрошується висновок: «державний пенсіонер» $i$ їсти хоче, $i$ погуляти вволю, а то $і$ на курорт за старою звичкою гайне!.. А іншим пенсіонерам - зась?! [УС. 25-31.12.2003]; в) сарказм - Але тоді владі слід про це заявити щиро і відверто - хіба тут, мовляв, до культури, коли про чиюсь власність йдеться? [УМ. 01.08.2003] і т. ін. Нерідко риторичні питання виражають спонукання: Спробуй ще десь навіть у масштабах колишнього $\mathrm{Pa}$ дянського Союзу знайти подібне зібрання тих же корисних копалин, які видобувають у регіоні? [УМ. 01.08.2003] (коментарний підстиль).

Іронічною інтонацією може бути позначене риторичне запитання і у власне інформаційному різновиді: Більше того: росіяни, обурюється керівник «Почерку», вилучили ("бєз суда і слєдствія - по понятіям «добрососсдства»? - Авт.) чотири тонни риби, взятої екіпажем «Ялти» згідно з розподілом квот між Росією та Украӥною [УМ. 25.02.2009] - риторичне запитання є вставленим реченням, увиразнює висловлення, відображає авторське судження. У власне інформаційному підстилі риторичні запитання висловлюють інколи очікування: Чергова обіиянка дніпропетровської влади - відкрити соціальні магазини. Чи дотримає вона слова цього разу? [ВП. 12.03.2009]; I якщо Кабмін на чолі з пані Тимошенко таки не виділить кошти, а експертиза «плівок Мельниченка» за участю фахівців із Німеччини та Румунії буде зірвана, доповідь нардепа перед євроспільнотою мо- 
же мати зовсім інші акценти: чи не варто, окрім підбурювачів $і$ замовників злочину, встановити й тих, хто «покриває» головних і поки щзо непокараних фігурантів справи? [УМ. 21.02.2009] - в останньому прикладі риторичне питання є частиною складної синтаксичної конструкції. Але часто у власне інформаційних текстах риторичні питання надають висловленню стриманої виразності і є простими за будовою реченнями: Що, гривня, холодно? Національна валюта і далі падає [УМ. 14.01.2009]; Незважаючи на супероснащуення, лікування в такому закладі буде доступним для всіх. Звучить як казка? [ВП. 09.04.2009]; Куди зникає свято? У компост! Ялинки можуть прислужитись людям і після Нового року [УМ. 21.01.2009].

Риторичні питання спільної тематики здатні об'єднувати навколо себе ширший за обсягом текст, увиразнювати проблему, виступати показниками загального тону мовлення: Хто вони в нашому жситмі, ці колишні? Hi, не обов'язково ті, чиї імена були щзе десять-n'ятнадиять чи й двадиять років тому в усіх на вустах. А просто - колишні вчителі чи інженери, працуівники міліції, доярки чи робітники. Ті, кому ми, нині сущзі, прийили на зміну. Хто вони, невже просто перегорнута й забута сторінка історії, від якої віс не нашими настроями, не нашими нинішніми переконаннями, просто опале листя минулої осені, крізь яке вже пробивасться молода трава? Господи, яка ж банальна істина про те, щуо рівень розвитку суспільства визначається ставленням до престарілих $i$ дітей. Та хіба якась, нехай і найдосконаліша, соціальна програма тут може заради$\boldsymbol{m} \boldsymbol{u}$ ? [СВ. 30.04.2009] (коментарний різновид).

Якщо риторичне звертання є заголовком інформаційного тексту, воно увиразнює назву емоційно-смисловими відтінками: ПРіБЮТ чи не ПРіБЮТТ? Над Верховною Радою знову витає привид коаліиії «регіоналів» $i$ «тимошенківців» [УМ. 17.04.2009] - простежується позиція автора; Ющзенко хоче, щзоб своє слово сказав народ. Але яким буде це слово? [УМ. 16.04.2009] (коментарне мовлення). Нерідко риторичні запитання виносяться в заголовок власне інформаційних текстів: Підемо попідтинню? Вітчизняні економісти загрозу дефолту в Україні вважають перебільшенням [УМ. 22.01.2009]; Розмитнена без насилля? На Буковині знайдено мертвим сина генерала митної служби Миколи Салагора, який звинуватив БЮТівиів, місиеве управління СБУ і Держмитслужбу в реалізації контрабандних схем [УМ. 13.01.2009].

Напруженню почуттів у риторичному питанні може допомагати взаємодія з іншими виражальними синтаксичними засобами, наприклад, парцеляцією, повтором: То невже ми повинні про цุе забути? Про мільйони душ, які були марно загублені, стравлені, знищені тогочасним режимом? Невже повинні змовчати перед дітьми?! [УС. 25-31.12.2003] (коментарний підстиль). Риторичне питання може відзначатися великим зарядом експресії, передусім у коментарному різновиді інформаційного стилю: A скажіть, де честь, де демократія, де правда? [3. 23.12.2004] (контамі- 
нація з синтаксичним паралелізмом); Чи то так багато звитяжників, «стахановців», генїв, чи орденокарбувальний завод забуває вимкнути верстат? Але в задачі стоїть запитання: якщо звитяжників - полки, то чому Вітчизна у скруті? [УМ. 24.01.2009] (однорідні члени речення посилюють загальний іронічний тон).

Риторичне питання нерідко поєднується з анафорою. При цьому воно загострює увагу адресата на якій-небудь думці, у той час як паралелізм і анафора посилюють експресію: $A$ керівникам політичних партій, які входять до опозичійних сил, треба задуматись над одним питанням: «Чи здатні вони повести за собою людей, щзоб вони стали громадянами незалежної держави? Чи здатні вони повести за собою населення, яке, піднімаючись з колін, можливо, роблячи перші кроки тремтячими ногами, ставатиме народом і нацією?» [УС. 25-31.12.2003] (коментарне мовлення). Риторичні питання в поєднанні $з$ анафорою є нехарактерними для власне інформаційного підстилю.

Опрацювання інформаційних текстів, уміщених на сторінках газет «Вісті Придніпров’я», «Дзеркало тижня», «Зоря», «Українське слово», «Україна молода», «Сільські вісті» дозволило зробити наступні висновки про функціонування риторичних питань в інформаційному мовленні. Риторичні питання вживаються 3 метою привернення уваги до ситуації, емоційного підкреслення думки / події; несуть у собі відтінки подиву, іронії, виражають напруження почуттів, спонукають до роздумів, висловлюють авторське ставлення. Риторичні питання можуть взаємодіяти 3 іншими виражальними засобами синтаксису, наприклад, анафорою, парцеляцією.

Неоднаковим за частотністю і ступенем виразності $є$ уживання риторичних питань в інформаційних підстилях. Надзвичайно рідко зустрічаються риторичні питання у власне інформаційних текстах і $є$ переважно дещо стриманішими в емоційно-експресивному аспекті, ніж риторичні питання в коментарному мовленні. Посилено виразні риторичні питання у власне інформаційному підстилі виявлені в цитуваннях, вкраплених до текстів інформацій, заміток тощо. Коментарний різновид характеризується рідким уживанням риторичних питань, помітних завдяки своїй виразності та взаємодії з іншими стилістичними фігурами синтаксису.

\section{Лiтература}

1. Ван Синьи. Фигуры речи как реализация параллелизма и их назначение в публицистике // Журналистика и культура русской речи. - 2004. - № 1. - С. 7-10.

2. Ващенко В. С. Стилістичний синтаксис // Сучасна українська літературна мова: Стилістика / За ред. І. К. Білодіда. - К.: Наук. думка, 1973. - С. 339-464.

3. Дудик П. С. Стилістика української мови: Навч. посібник. - К.: ВЦ «Академія», 2005. - 368 с. (Альма-матер)

4. Лихошерст Н. И. Стилистический синтаксис // Стилистика английского языка: Учебник / А. Н. Мороховский, О. П. Воробъева, Н. И. Лихошерст, З. В. Тимошенко. - К.: Выща шк., 1991. - С. 137-163. 
5. Мацько Л. І., Мащько О. М. Риторика: Навч. посібник. - К.: Вища шк., 2003. - 311 с.

6. Франко 3. T. Риторичне питання // Українська мова: Енциклопедія / Редкол.: В. М. Русанівський (співголова), О.О.Тараненко (співголова), П. К. Зяблюк (заст. гол.), С. А. Карпіловська (відпов. секретар). - Вид. II, виправл. і доп. К.: Вид-во «УЕ» ім. М. П. Бажана, 2004. - С. 551.

\section{Список використаних джерел}

ВП - «Вісті Придніпров'я» - обласна газета

ДТ - «Дзеркало тижня» - міжнародний громадсько-політичний тижневик

3 - «Зоря» - Народна газета Дніпропетровщини

CВ - «Сільські вісті» - загальнополітичне видання, газета захисту інтересів селян України

УМ - «Україна молода» - щоденна інформаційно-політична газета

УС - «Українське слово» - Всеукраїнський громадсько-політичний тижневик 